\title{
PENERAPAN MODEL COOPERATIVE LEARNING UNTUK MENINGKATKAN HASIL BELAJAR SISWA MATA PELAJARAN PKN KELAS IV SD NEGERI 162091 KOTA TEBING TINGGI
}

\author{
Nurleni \\ Guru SD Negeri 162091 Kota Tebing Tinggi \\ Surel: nurleni91@gmail.com
}

\begin{abstract}
ABSTRAK
Penelitian ini bertujuan untuk meningkatkan hasil belajar siswa mata pelajaran PKn melaui model pembelajaran Cooperative Learning. Penelitian tindakan kelas ini dilaksanakan sebanyak 3 siklus dengan empat tahapan yaitu : perencanaan, pelaksanaan, observasi, refleksi. Subjek penelitian ini adalah siswa kelas IV SDN 162091 Tebing Tinggi sebanyak 33 siswa. Penelitian ini menggunakan teknik analisis dekriptif kualitatif. Hasil penelitian menunjukkan bahwa penggunaan model pembelajaran Cooperative Learning mata pelajaran $\mathrm{PKn}$ materi globalisasi dapat meningkatkan hasil belajar siswa yang ditandai dengan peningkatan ketuntasan belajar siswa, yaitu pra siklus $(60,60 \%)$, siklus I $(69,69 \%)$, siklus II $(78,78 \%)$, siklus III $(90,90 \%)$ dan dinyatakan berhasil ssecara klasikal 90,90\%.
\end{abstract}

Kata Kunci : Cooperative learning, Hasil belajar

PENDAHULUAN

Pembelajaran Pendidikan

Kewarganegaraan (Citizenship) merupakan pembelajaran yang memfokuskan pada pembentukan diri yang beragam dari segi agama, sosio-kultural, bahasa, usia dan suku bangsa untuk menjadi warga negara yang cerdas, terampil, dan berkarakter yang diamanatkan oleh Pancasila dan UUD 1945 (Tim Media, 2005: 11) Melalui PKn setiap warga negara dapat mawas diri dengan perkembangan globalisasi, teknologi informasi dan komunikasi dewasa ini yang memberi dampak positif dan negatif.

PKn juga bermanfaat untuk membekali peserta didik agar dapat menarik manfaat dari arus globalisasi dan dapat menangkal pengaruh- pengaruh negatif yang dapat mengancam jati diri dan identitas bangsa. Menurut Held (2000: 397), globalisasi dapat dipahami sebagai perubahan-perubahan dalam bidang ekonomi dan sosial yang berkombinasi dengan pembentukan kesalinghubungan regional dan global yang unik, yang lebih ekstensif dan intensif dibandingkan dengan periode sebelumnya, yang menantang dan membentuk kembali komunitas politik, dan secara spesifik, negara modern.

Dalam proses pembelajaran diperlukan adanya hubungan timbal balik antara guru dan siswa sehingga terjalin komunikasi dua arah yang menjadikan pembelajaran terarah pada pencapaian kompetensi. Guru harus mampu memahami beberapa 
hal dari peserta didik seperti kemampuan, potensi, minat, hobi, sikap, kepribadian, kebiasaan, catatan kesehatan, latar belakang keluarga, dan kegiatannya di sekolah.

Disamping pelaksanaan proses pembelajaran dalam suasana komunikasi dua arah, diharapkan siswa juga dapat melakukannya dalam suasana komunikasi multi arah. Dalam proses pembelajaran seperti ini hubungan tidak hanya terjadi antara seorang guru dengan siswa dan sebaliknya, tetapi juga antara siswa-siswa lainnya (Muhibbin Syah, 2005: 238). PKn dianggap ilmu yang sangat membosankan dan dianggap remeh oleh siswa. PKn adalah pelajaran formal yang berupa sejarah masa lampau, perkembangan sosial budaya, tata cara hidup bersosial, serta peraturan kenegaraan yang dianggap tidak menarik untuk dipelajari karena umumnya mempelajari tentang ketatanegaraan dan pemerintahan. Di kelas IV selama ini siswanya masih kurang aktif dalam hal bertanya dan menjawab, bosan dengan metode pembelajaran yang membosankan, hasil yang dicapai siswa kelas IV sangat jauh dari memuaskan, dimana hanya mendapat daya serap kurang dari berdasarkan analisis situasi/latar belakang diatas maka penulis berkeinginan untuk memperbaiki/mengadakan inovasi pembelajaran.

Masalah yang sering dihadapi pada mata pelajaran PKn di SD
Negeri 162091 Tebing Tinggi adalah mata pelajaran PKn dianggap mata pelajaran yang membosankan sehingga siswa kurang berminat untuk mengikuti pembelajaran PAK. Selain itu metode belajar PKn lebih sering menggunakan metode ceramah ataupun hanya menggunakan LKS. Hal tersebut menyebabkan siswa menganggap remeh dan semakin tidak berminat untuk mengikuti pelajaran PKn.

Metode mengajar yang diterapkan oleh guru PKn pada umumnya adalah metode konvensional. Guru dianggap sebagai gudang ilmu, otoriter dan mendominasi kelas, mengajarkan ilmu, langsung membuktikan dalildalil dan memberikan contoh. Sedangkan siswa harus duduk rapi mendengarkan, meniru dan mencontoh cara-cara yang diterapkan guru serta menyelesaikan soal-soal atau tugas-tugas yang diberikan guru tanpa ada tindakan lebih lanjut mengenai tugas tersebut.

\section{Penggunaan}

metode

Cooperative Learning diharapkan dapat meningkatkan pemahaman dan meningkatkan hasil belajar siswa mengenai materi pelaran PKn materi globalisasi. Cooperative Learning adalah suatu model pembelajaran yang saat ini banyak digunakan untuk mewujudkan kegiatan belajar mengajar yang berpusat pada siswa atau student oriented, terutama untuk mengatasi permasalahan guru dalam mengaktifkan siswa (Isjoni, 2009:16). Dalam strategi Cooperative Learning, siswa belajar 
dalam pasang-pasangan atau kelompok untuk saling membantu memecahkan problem yang dihadapi. Cooperative learning ini lebih menekankan pada lingkungan sosial belajar dan menjadikan kelompok belajar sebagai tempat untuk mendapatkan pengetahuan, mengeksplorasi pengetahuan (Baharuddin dan Esa, 2007:128).

Menurut Martati (2010:15)

Tujuan Cooperative Learning dikembangkan paling sedikit tiga tujuan penting, yaitu tujuan yang pertama Cooperative Learning dimaksudkan untuk meningkatkan aktivitas siswa dalam tugas-tugas akademis yang penting. Tujuan kedua adalah toleransi dan penerimaan yang lebih luas terhadap orang-orang yang berbeda ras, budaya, kelas sosial, atau kemampuannya. Tujuan ketiga adalah mengajarkan keterampilan kerjasama dan berkolaborasi kepada siswa.

Menghadapi kenyataan tersebut di atas, penulis tertarik untuk mendalami dan melakukan tindakan - tindakan perbaikan pembelajaran PKn, khususnya materi Negara Kesatuan Republik Indonesia (NKRI) melalui penelitian tindakan kelas. Perbaikan yang penulis lakukan mengenai penerapan metode bermain peran pada materi "Globalisasi". Maka dari itu penulis tertarik untuk melakukan penelitian tindakan kelas yang berjudul "Penerapan Model Cooperative Learning Untuk Meningkatkan Hasil Belajar Siswa Mata Pelajaran PKn
Kelas IV SD Negeri 162091 Kota Tebing".

Berdasarkan uraian pada latar belakang masalah, maka dapat dirumuskan permasalahan sebagai berikut: "Apakah dengan menggunakan pembelajaran model Cooperative Learning dapat meningkatkan hasil belajar PKn siswa kelas IV SD Negeri 162091 kota Tebing Tinggi?"

Tujuan dari penelitian ini adalah untuk meningkatkan hasil belajar PKn siswa kelas IV SD Negeri 162091 kota Tebing Tinggi melalui pembelajaran Cooperative Learning.

\section{METODE PENELITIAN}

$\begin{array}{cll}\text { Penelitian } & \text { ini } & \text { adalah } \\ \text { penelitian tindakan } & \text { kelas } & \text { (PTK), }\end{array}$ yang terdiri dari 3 siklus. Penelitian ini dilakukan dari bulan AgustusSeptember 2013. Subyek penelitian adalah siswa kelas IV SD Negeri 162091 Tebing Tinggi semester I tahun 2013/2014 dengan jumlah siswa sebanyak 33 orang dengan 14 orang laki-laki dan 19 orang perempuan. Sumber data yang digunakan adalah siswa dan teman sejawat.Alat pengumpul data dalam penelitian ini adalah tes yang disusun oleh Guru. Pada Penelitian tindakan kelas data yang dikumpulkan dapat berbentuk kuantitatif maupun kualitatif.

Penelitian tindakan kelas ini terdiri dari 3 siklus dan setiap siklusnya terdiri dari: perencanaan, tindakan, pengamatan, dan refleksi. 
Masing-masing siklus terdiri dari dua kali pertemuan yaitu sebagai berikut:

\section{Perencanaan}

Sebelum
penelitian peneliti $\begin{array}{r}\text { mengadakan } \\ \text { menun }\end{array}$
rumusan masalah, tujuan dan
membuat rencana tindakan, termasuk
di dalamnya RPP, LKS, instrumen
penelitian dan perangkat
pembelajaran.

\section{Pelaksanaan}

\section{a. Siklus I}

Dengan bimbingan guru, siswa membentuk kelompok secara heterogen. Guru melakukan pembelajaran di dalam kelas dengan menggunakan panduan perencanaan yang telah dibuat. Penerapan metode Cooperative Learning dilakukan dengan menugaskan kepada masingmasing kelompok untuk mendiskusikan materi yang dibahas. Pada saat kegiatan pembelajaran berlangsung guru sebagai peneliti dibantu oleh para observer lainnya untuk melakukan pengamatan, pendokumentasian, selain itu peneliti bertindak sebagai fasilitator, motivator dan sekaligus sebagai pengamat.

\section{b. Siklus II}

Guru melakukan pembelajaran di dalam kelas dengan menggunakan panduan perencanaan yang telah dibuat. Materi yang diajarkan guru sesuai dengan materi sistem pemerintahan desa dan kecamatan. Pada Siklus kedua ini juga, suasana pembelajaran masing- masing kelompok di lingkungan sekolah dikondisikan agar tidak terlalu formal, maksudnya siswa bebas mengemukakan pendapatnya tentang materi ajar sesuai dengan kompetensi dasar yang ingin dicapai.

\section{c. Siklus III}

Perencanaan metode Cooperative Learning dilakukan dengan menugaskan kepada masingmasing kelompok untuk mendiskusikan materi yang diajarkan guru dengan materi sistem pemerintahan desa dan kecamatan. Pada siklus III ini, siswa sudah terbiasa dengan metode belajar inquiri sehingga siswa tidak canggung untuk berdiskusi ataupun mengajukan pertanyaan.

\section{Observasi/Pengamatan}

Pengamatan dilakukan peneliti sendiri dan dibantu oleh pengamat dan mencatat proses penerapan teknik pengajaran kolaborasi. Pengamatan dilakukan terhadap pelaksanaan tindakan berdasarkan jurnal harian, lembar observasi aktivitas guru dan siswa, dan tes hasil belajar yang telah diisi oleh siswa, pengamat, dan guru mitra. Mencatat kelebihan dan kekurangan selama proses pembelajaran dengan model Cooperative Learning baik guru peneliti atau siswa oleh pengamat atau guru mitra.

\section{Refleksi}

Kegiatan pada tahap refleksi meliputi kegiatan menganalisis, memahami dan membuat kesimpulan 
berdasarkan hasil observasi setiap siklus. Menemukan kelebihan dan kelemahan tindakan perbaikan pembelajaran. Hasil analisis data yang dilaksanakan pada tahap ini akan dipergunakan untuk menemukan kelebihan dan kelemahan diri dalam merancang dan melakukan tindakan sebagai acuan. Peneliti mengkaji, melihat dan mempertimbangkan hasil atau dampak dari tindakan yang dilakukan berdasarkan lembar pengamatan yang diisi oleh pengamat. Tahapan ini dilakukan secara berkesimbungan sehingga ditemukan hasil yang optimal.

Penelitian tindakan kelas tidak menggunakan uji statistik, tetapi dengan deskriptif. Data kuantitatif yang berupa nilai dianalisis dengan menggunakan analisis deskriptif komparatif yaiu membandingkan nilai tes kondisi awal, nilai tes setelah siklus I, II dan siklus III yaitu nilai dari hasil ulangan harian siswa kelas IV SD Negeri 162091. Komponen pengajaran model Cooperative Learning yaitu data kuantitatif dan kualitatif yang berupa observasi kegiatan guru, dan sisa serta data kuantitatif yang berupa nilai hasil ulangan harian siswa kelas IV.

\section{HASIL PENELITIAN PEMBAHASAN}

Sebelum

penelitian

dilakukan, terlebih dahulu peneliti mengadakan survei pra siklus pada minggu sebelumnya. Peneliti mengidentifikasi masalah melalui pengamatan proses belajar mengajar yakni rendahnya hasil belajar siswa pada kelas IV SD Negeri 162091 Tebing Tinggi mata pelajaran PKn. Kegiatan ini dilakukan dengan tujuan menyampaikan maksud mengadakan penelitian tindakan kelas dengan menerapkan metode eksperimen untuk meningkatkan aktivitas siswa dalam proses pembelajaran. Pada pengamatan dilakukan dengan menggunakan lembar observasi aktivitas siswa dan menggunakan penilaian hasil evaluasi melalui ulangan harian. Jumlah siswa yang lulus pada hasil evaluasi yang dilakukan adalah sebanyak 20 siswa memenuhi kriteria nilai KKM dari 33 siswa.

Hasil penelitian tindakan
kelas menunjukkan bahwa pengamatan yang dilakukan oleh mitra kolaborasi dan peneliti pada aktivitas guru dan siswa melalui penerapan model Cooperative Learning pada mata pelajaran PKn materi globalisasi, kelas IV SD Negeri 162091 Tebing Tinggi dapat dilihat pada Tabel 1 yaitu sebagai berikut:

\section{Tabel Peningkatan Hasil Belajar} Siswa Siklus I, II dan III

\begin{tabular}{|c|c|c|c|c|}
\hline \multirow{2}{*}{ Keterangan } & \multicolumn{4}{|c|}{ Peningkatan Hasil Belajar } \\
\cline { 2 - 5 } & $\begin{array}{c}\text { Pra } \\
\text { siklus }\end{array}$ & $\begin{array}{c}\text { Sikus } \\
\text { I }\end{array}$ & $\begin{array}{c}\text { Siklus } \\
\text { II }\end{array}$ & $\begin{array}{c}\text { Siklu } \\
\text { s III }\end{array}$ \\
\hline $\begin{array}{c}\text { Nilai } \mathrm{x}- \\
\text { ulangan } \\
\text { harian }\end{array}$ & 67,58 & 70,30 & 71,96 & 72,87 \\
\hline $\begin{array}{c}\text { Jumlah } \\
\text { siswa }\end{array}$ & 20 & 23 & 26 & 30 \\
\hline $\begin{array}{c}\text { Persen } \\
\text { Ketuntasan } \\
\text { Belajar (\%) }\end{array}$ & 60,60 & 69,69 & 78,78 & 90,90 \\
\hline
\end{tabular}




\section{Berdasarkan pengamatan} peneliti dari tindakan pra siklus, siklus I, siklus II dan siklus III pada Tabel 1 terjadi peningkatan hasil belajar pada jumlah siswa dan persen ketuntasan belajar secara klasikal. Hal ini dapat dilihat dengan peningkatan jumlah siswa dari 20 siswa yang tuntas belajar pada pra siklus menjadi 30 siswa yang tuntas belajar melalui model pembelajaran Cooperative Learning materi globalisasi pada siswa kelas IV SD Negeri 162091 Tebing Tinggi.

Kemampuan siswa pada pra siklus dalam memahami sistem pemerintahan di Indonesia dari tingkat desa sampai dengan tingkat pusat masih rendah. Aktivitas siswa pada pra siklus dalam mendengarkan/memperhatikan

penjelasan guru, mengerjakan tugas yang diberikan guru, keantusiasan siswa mengikuti pelajaran, menuliskan dan menyampaikan hasil percobaan, bekerjasama dan berdiskusi dengan kelompok juga masih rendah maka dari itu dilakukan penelitian siklus I.

Rendahnya

persentase

ketuntasan belajar siswa pembelajaran PKn dipengaruhi oleh beberapa hal yaitu: siswa selalumenganggap bahwa pelajaran PKn merupakan pelajaran yang sepele karena mata pelajaran PKn tidak diujikan pada Ujian Nasional, siswa cepat merasa bosan, siswa cenderung mengahafal materi dibandingkan memahami materi tersebut sehingga tak jarang siswa cepat lupa materi yang telah diajarkan sebelumnya.

Hasil ulangan siswa pada pelajaran PKn di kelas IV masih sesuai standard kelulusan, yaitu memperoleh nilai rata-rata 70,30 sedangkan Kriteria Kelulusan Minimal (KKM) yang harus dicapai siswa adalah 70. Dari 33 orang siswa yang mengikuti ujian pada pelajaran PKn hanya 23 orang siswa atau 69,69\% yang berhasil mendapatkan nilai di atas nilai 70 , sedangkan 10 orang siswa atau 30,30\% mendapat nilai di bawah nilai 70 . Hasil tersebut menunjukkan bahwa pada siklus pertama secara klasikal siswa belum tuntas belajar, karena siswa yang memperoleh nilai $\geq 65$ hanya sebesar 69,69\% lebih kecil dari persentase ketuntasan yang dikehendaki yaitu sebesar $85 \%$.

Pada siklus I, secara garis besar kegiatan belajar mengajar dengan metode pembelajaran Cooperative Learning dilaksanakan belum dengan baik, peran guru masih cukup dominan untuk memberikan penjelasan dan arahan, karena model tersebut masih dirasakan baru oleh siswa. Siswa masih kurang aktif dalam kegiatan pembelajaran karena belum terbiasa dengan metode pembelajaran Cooperative Learning.

\section{Kemampuan} siswa/ kelompok dalam mengerjakan tugas, berargumen, keaktifan, kerjasama, motivasi dan lain-lain masih dinilai kurang. Pada saat guru menyuruh setiap kelompok mempresentasikan hasil diskusinya, ada siswa yang 
memperhatikan, ada yang asik sendiri dan ribut tidak memperhatikan. Kemudian siswa dan guru bersama-sama mengevaluasi kegiatan, selain itu guru juga memberikan penguatan, dorongan serta penghargaan bagi kelompok.

Pada Tabel 1, metode pembelajaran Cooperative Learning pada materi globalisasi diperoleh nilai rata-rata hasil belajar siswa adalah 71,96 dan ketuntasan belajar mencapai $78,78 \%$ atau ada 26 siswa dari 33 siswa sudah tuntas belajar. Hasil tersebut menunjukkan bahwa pada siklus pertama secara klasikal siswa belum tuntas belajar, karena siswa yang memperoleh nilai $\geq 65$ hanya sebesar 78,78\% lebih kecil dari persentase ketuntasan yang dikehendaki yaitu sebesar $85 \%$. Adanya peningkatan hasil belajar siswa ini karena siswa-siswa telah mulai terbiasa dengan model pembelajaran Cooperative Learning yang diberikan oleh guru sehingga mereka terbiasa berdiskusi dengan aktif di dalam kelompok mereka masing masing dalam upaya meningkatkan pemahaman mereka terhadap materi yang disampaikan. Saat di kelas, guru juga berusaha meminta setiap anggota kelompok untuk bertanya dan mengemukakan ide mengenai materi pelajaran. Maka dari itu, dilanjutkan ke siklus sebelumnya.

Pada siklus II, secara garis besar kegiatan belajar mengajar dengan model pembelajaran Cooperative Learning dilaksanakan belum dengan baik dan masih ke dalam kategori cukup baik. Pada saat guru menyuruh setiap kelompok mempresentasikan hasil diskusinya, hampir semua siswa serius meskipun ada yang kurang fokus dan tidak memperhatikan. Kemudian siswa dan guru bersama-sama mengevaluasi kegiatan, selain itu guru juga memberikan penguatan, dorongan serta penghargaan bagi kelompok. Beberapa aspek yang mendapat nilai kurang baik di atas merupakan suatu kelemahan yang terjadi pada siklus II dan akan dijadikan bahan kajian untuk refleksi dan revisi yang akan dilakukan pada siklus III.

Dari tabel 1 dapat dilihat bahwa siklus III dengan menerapkan modelpembelajaran Cooperative Learning pada materi "globalisasi" diperoleh nilai rata-rata tes Ulangan Harian sebesar 72,87 dan dari 33 siswa yang telah tuntas sebanyak 30 siswa dan 3 siswa belum mencapai ketuntasan belajar. Maka secara klasikal ketuntasan belajar yang telah tercapai sebesar 90,90\% (termasuk kategori tuntas). Hasil pada siklus III ini mengalami peningkatan lebih baik dari siklus II. Adanya peningkatan hasil belajar pada siklus III ini dipengaruhi oleh semangat siswa yang meningkat dan sudah terbiasa dengan model pembelajaran Cooperative Learning yang disampaikan oleh guru. Saat melaksanakan diskusi dengan pasangannya, siswa sudah mulai aktif melaksanakan kegiatan diskusi dengan baik dan memecahkan 
masalah terhadap teks materi yang diberikan oleh guru. Nilai tersebut sudah melebihi dari persentase ketuntasan yang dikehendaki yaitu sebesar $85 \%$.

Aspek - aspek yang diamati pada kegiatan belajar mengajar (siklus III) yang dilaksanakan oleh guru dengan menerapkan metode pembelajaran Cooperative Learning mendapatkan penilaian baik dari pengamat adalah mempresentasikan langkah-langkah metode pembelajaran Cooperative Learning dan membimbing siswa melakukan kegiatan. Penyempurnaan aspekaspek diatas dalam menerapkan metode pembelajaran Cooperative Learning dengan meninjau ulang diharapkan dapat berhasil semaksimal mungkin.

Hasil tes yang dilakukan pada siklus III menunjukkan hasil yang sangat memuaskan dimana sebesar 90,90\% siswa atau dari 33 siswa yang telah tuntas sebanyak 30 siswa dan 3 siswa belum mencapai ketuntasan belajar. Dari hasil tes ini dapat dilihat bahwa hasil belajar dengan menggunakan pembelajaran Cooperative Learning telah mampu meningkatkan hasil belajar siswa mengenai materi pelajaran PKn sesuai dengan indikator yang telah ditentukan sehingga tidak perlu lagi dilanjutkan pada siklus berikutnya dan dikatakan berhasil.

Penggunaan metode Cooperative Learning diharapkan dapat meningkatkan pemahaman dan meningkatkan hasil belajar siswa mengenai materi pelaran PKn materi globalisasi. Cooperative Learning adalah suatu model pembelajaran yang saat ini banyak digunakan untuk mewujudkan kegiatan belajar mengajar yang berpusat pada siswa atau student oriented, terutama untuk mengatasi permasalahan guru dalam mengaktifkan siswa (Isjoni, 2009:16).

Berdasarkan hasil yang didapat dari setiap siklus proses pembelajaran yang optimal, hal ini ditunjukkan dengan meningkatnya penguasaan materi dan hasil belajar siswa. Oleh karena itu dapat disimpulkan bahwa proses pembelajaran dengan penerapan Cooperative Learning sangat sesuai dengan mata pelajaran PKn. maka Penelitian Tindakan Kelas (PTK) ini bisa dikatakan berhasil karena hasil peningkatan proses pembelajarannya optimal.

\section{KESIMPULAN}

Dari hasil temuan penelitian tentang hasil belajar siswa dengan metode eksperimen di kelas IV SD Negeri 162091 Tebing Tinggi tahun pelajaran 2013/2014 berdampak positif dalam meningkatkan hasil belajar siswa. Hal tersebut dapat dilihat dari peningkatan persentase ketuntasan belajar siswa pada pra siklus $(60,60 \%)$, siklus I $(69,69 \%)$, siklus II $(78,78 \%)$, dan siklus III $(90,90 \%)$.

Atas dasar simpulan dan implikasi hasil penelitian tindakan kelas di atas, penulis memberikan saran-saran sebagai berikut : 
a. Bagi Sekolah

Sebaiknya menyediakan sarana yang dapat mendukung kegiatan belajar mengajar dan memperbanyak sarana pendukung dalam kegiatan belajar mengajar.

b. Bagi Guru

Sebaiknya guru memanfaatkan waktu secara efektif antara lain membatasi presentasi kelompok di depan kelas dengan cara memilih beberapa kelompok saja yang mewakili presentasi.

c. Bagi Siswa

Siswa diharapkan untuk turut berperan aktif dalam proses pembelajaran di kelas terutama saat diskusi kelompok.

\section{DAFTAR RUJUKAN}

A Held, David. 2000. "Regulating Globalization? The Reinvention Politics" International Sociology. 15 (2): 394-408.

Baharuddin, dkk, .2007. Teori Belajar dan Pembelajaran. Yogyakarta: RUZZ Media.

Isjoni. 2009. Cooperative Learning Mengembangkan

Kemampuan Belajar

Bekelompok. Bandung:

Alfabeta.

Martati, Badruli. 2010. Metodelogi Pembelajaran Pendidikan Kewarganegaraan.

Bandung: Genesindo.

Muhibbin Syah. 2005. Psikologi Pembelajaran. Jakarta: PT Raja Grafindo Persada. 